2018-02-22

Policing Extreme Political Protest: A

Historical Evaluation of Police Prejudice

Channing, lain

http://hdl.handle.net/10026.1/11152

10.1093/police/pay010

Policing

Oxford University Press (OUP)

All content in PEARL is protected by copyright law. Author manuscripts are made available in accordance with publisher policies. Please cite only the published version using the details provided on the item record or document. In the absence of an open licence (e.g. Creative Commons), permissions for further reuse of content should be sought from the publisher or author. 


\author{
lain Channing \\ School of Law, Criminology and Government, Plymouth University
}

\title{
Policing extreme political protest: A historical evaluation of police prejudice
}

\begin{abstract}
The task of policing political activism frequently tests the legitimacy of the police leaving them vulnerable to claims of political prejudice. The principle of police neutrality has been subjected to criticism by MPs, activists and academic scholars since the formation of the modern police force. Members of both far right and far left movements have claimed their liberty to protest has been curtailed at different moments and much academic scholarship has highlighted the pro-fascist nature of policing. This article redresses the balance to provide a deeper understanding of the way political activism was (and continues to be) policed. In recent years, protests involving the English Defence League and the Occupy movement have highlighted the contemporary challenges to public order operations. Both groups have questioned the political impartiality of the police. Yet, these accusations are not new and by offering a historical comparison to the policing of extreme political activism in the interwar years, concerns regarding police culture, discretion, and legitimacy in the contemporary era are addressed. The inconsistent policing of the British Union of Fascists and the Communist Party of Great Britain frustrated both groups, and this article challenges existing research which claims that a pro-fascist motivation in policing accounts for this inconsistency. By exploring other motivations, it argues that we should not see the police as a monolithic institution with a particular view, and although political partiality is still significant, other key factors such as legal ambiguity, police pragmatism and regional variations must also be taken into account.
\end{abstract}

\section{Introduction}

The policing of political protest is an unavoidably political process itself. Within the context of England and Wales, there has long been a tradition that has limited the extent to which freedom of expression can be articulated. Therefore, restrictions placed upon political protests will inherently be judged in relation to their consistent application across different political groups. Yet, the police will inevitably use their discretion to implement the wide choice of legal powers they have at their disposal. In the present day, this will include their bewilderingly ambiguous common law powers under the breach of the peace doctrine (Stone, 2001; Fenwick, 2009). In addition to this, the police hold powers under the Public Order Act 1986 which regulates threatening or offensive words or behaviour, and enables them to prohibit public 
processions and place conditions on public assemblies. Other powers relate to the obstruction of the highway (Highway Act 1980) and the provision of various stop and search powers (Police and Criminal Evidence Act 1984 and s60 Criminal Justice and Public Order Act 1994). Finally, whatever actions are taken by the police at political protests, their actions also currently have to adhere to the Human Rights Act 1998, which includes a legal commitment to the European Convention on Human Rights (ECHR).

The plethora of available laws, as well as their intrinsic ambiguity, undoubtedly provides the scope for inconsistent police practice that threatens both political objectivity and protestor perceptions of police legitimacy. This has been tested in recent years with the emergence of new far right movements which have reinvigorated political street activism. Formed in 2009, the English Defence League (EDL) have been the most prominent, while other groups such as Britain First and National Action have also necessitated a police response in order to preserve or restore public order. At the same time, anti-fascist groups have also organised counter-demonstrations which requires additional police resources to keep opposing factions apart. Added to this, there has also been a growth in anti-capitalist and anti-globalisation demonstrations such as the Occupy movement which have taken on particular resonance since the policy of austerity was enforced by the Conservative Liberal Coalition in 2010. For the police, this presents the problem of maintaining order whilst maintaining an image of impartiality and legitimacy. With reference to the EDL and the Occupy movement, this article examines the common accusations of police bias which are raised by both groups.

The question of remaining impartial when policing opposing political factions is not new. The historiography of political extremism in 1930s and 1940s Britain reveals a 
notion that pro-fascist and anti-left police partiality was prominent (Ewing and Gearty, 2000; Dorril, 2006; Renton, 2000). This article counters those assumptions, and although recognising that there is evidence to support biased policing in some cases relating to the British Union of Fascists (BUF) and the Communist Party of Great Britain (CPGB), it argues that other factors such as police pragmatism, regional variations, legal ambiguities, and the actions and tactics of the activists themselves also need to be appraised. The value of a historical criminological approach to the policing of political activism is that it reveals arguments and factors which still hold relevance today. As the law is in a continual state of development, a historical form of analysis becomes critical in understanding the law in its present form (Charlesworth, 2007; Bartlett, 2007). Additionally, the critique of the shortcomings of the historiography of the interwar years also serves as a warning to avoid the same pitfalls in assuming a police view in relation to the policing of political protest today.

\section{Historical Criminology and the policing of political protest}

Understanding the historical context which has either influenced or helped to create the present has long been a concern of researchers within the realms of crime and criminal justice (Newman and Ferracuti, 1980). Nevertheless, the amalgamation of historical research methods and those of the social sciences has not always been successfully implemented (Lawrence, 2012). For criminologists to meaningfully engage in historical research, it has to be concerned with not just the past, but also the present and the future. In this way historical study within criminology will not only aim to critically assess different responses to crime and forward a nuanced critique of contemporary policy issues, but it can also establish and assess longer term patterns in criminality, and track the continuity and change in regard to the social, cultural and political landscape that influenced them. 
In addressing the contemporary policing of the EDL and Occupy, criminologists have conducted influential ethnographic research which provides valuable insights into the activism and the culture of the protestors themselves (Winlow et al., 2015; Winlow et al., 2016; Treadwell, 2015; Burgum, 2015). Such research has revealed that activists on the political right and the left frequently claim to have received unjust police coercion while their political rivals enjoy more favourable treatment (see also, Oaten, 2014; Busher, 2013; Renton, 2017). Yet, such views are unsurprising as they help strengthen their own propaganda. It is because of the moral ambiguity inherent in public order policing that creates these tensions and a political group on the receiving end of police coercion is likely to question the legitimacy of police action (Waddington 1996). Caution must also be taken when reading reports, such as those conducted or distributed by the Network for Police Monitoring (NetPol). For example, Deshmukh (2016) focuses on the coercion of the anti-fascist demonstration which highlights the deterrent tactics deployed by the police to prevent people from attending a counter EDL protest. While the arguments presented raise valuable questions about the policing of protest, restraint must be applied before concluding that the police acted with political bias in order to protect the EDL demonstration.

Within the discipline of history, the debate about political police partiality in the 1930 s has frequently advocated that police practice, tactics and responses often demonstrated bias or partisanship in favour of the fascists when dealing with the problem of public disorder. Stevenson's (1980) contention that the Metropolitan Police in this era were 'anti-left' rather than 'pro-fascist', has been countered by Ewing and Gearty (2000, p. 296 n113) who identified that, 'the protestors on the receiving end of police militancy [would have seen] little difference between the two.' Historians, such as Richard Thurlow (2006) have highlighted that while the police at the highest level 
were not in favour of fascism, there were problems of interpreting the law at street level that led to inconsistent treatment of fascists and anti-fascists, but he stopped short of advocating that there was a political motivation for this. Other historians such as Lewis (1987) and Dorril (2006) acknowledged that political discrimination did exist in police practice. Lewis $(1987$, p. 161) categorically claimed 'beyond all doubt that instances of police bias did occur'. The debate opened here needs further evaluation and Thurlow's assertion that there were difficulties in interpreting the law requires strengthening by applying a legal lens as well as a retrospective application of police culture theory (Reiner, 2010; Loftus, 2009; Cockcroft, 2012). Without challenging the claims of pro-fascist policing would be to accept that the police are a monolithic institution with single political objective. This danger was highlighted by Emsley (1996, p. 176-7) who stated, it is:

too easy to assume that there was a "police view" with regard to politics and public order during the nineteen-thirties... [adding] the opinions of police constables were shaped by a variety of pressures and experiences and there are dangers in assuming a causal link between the conservative function of the police and the conservative principles in policemen.

Indeed, this 'view' is certainly easy to apply when considering the contemporary research on police cultures which highlights the trend in political Conservatism and moral conservatism of the police (Reiner, 2010; Loftus, 2009), as well as the history of suspicion and distrust between the police and activists on the political left (Alderson, 1984; Gorringe and Rosie, 2013). Additionally, the more recent failures of the Metropolitan Police Service regarding their policing of ethnic minority communities highlighted by Scarman (1981) and Macpherson (1999) have revealed the culture of division and suspicion between the police and minority communities. In the interwar period, evidence of anti-Semitism within the police also existed and Jewish 
communities were vulnerable to what would frequently be referred to today as hate crime whilst also feeling under protected from the police. ${ }^{1}$

Legal discretion and police culture are prominent elements of the policing of political activism in both eras under discussion. Firstly, common law and statutory law provide the legal framework that police officers must abide by. However, as has been shown, the ambiguity in the laws and the variety of legal responses to any one problem will naturally lead to inconsistent approaches because of such wide discretion (Channing, 2015). Secondly, if the police are able to use wide discretion when they enforce the law, the reasons for certain courses of action may become influenced by dominant cultures within the police (Reiner, 2010; Cockcroft, 2012; Chan, 1997; Loftus, 2009). Finally, the manifestation of negative police cultures, such as racial prejudice or their own social isolation which contributes towards the negative categorizing of certain communities as 'rubbish' or 'police property' only serves to damage police legitimacy. Within the arena of policing political activism this will have the detrimental effect of increasing crowd militancy to police instruction.

Another neglected side of police discretion that could serve some justification for the differences in the policing of the far left and the far right is that of pragmatism. This argument resonates with PAJ Waddington (1994) whose ethnographic research with a public order unit within the Metropolitan Police identified pragmatism as a key factor for police decision making. In Liberty and Order, Waddington argued that coercion and confrontation were often avoided in order to evade being held accountable by senior officers. Additionally, Cockcroft (2012) has also added to the argument that

\footnotetext{
${ }^{1}$ In particular, see Hull History Centre, U DCL/75/2, 'Police Behaviour at Stepney Green'. The National Council for Civil Liberties collected statements from witnesses who heard police officers shout 'run these f___ Jews down if they don't get out of the way' and other Jewish victims told of the brutality of the police towards them whilst using language like 'Jew bastard'.
} 
pragmatism has been present in relation to the policing of the BUF in the interwar period. This was in reference to Robert Skidelsky's (1975) biography of Mosley that portrayed a sympathetic view of both his subject and the policing of the BUF's activism. For Skidelsky to rely so steadfastly on such an argument is particularly naive as we must except that anti-Semitism and pro-fascist policing did exist, but that does not mean that other factors such as pragmatism should be written off as a contributing feature to public order policing. In addition, it must also be considered that pragmatic approaches to public order do not necessarily legitimise police tactics, and may still be perceived as coercive or partial by different political groups.

The problems faced by the police in relation to 'extreme' political activists are addressed in the 1930s and 2010s. As Backes (2010) argues, the meaning of 'extremism' changes depending on its historical context, yet the values of 'extremist' movements are considered to be the antithesis of those of the constitutional state, which values peaceful means of exerting influence and power whilst recognising the presence of other parties. 'Extremist' groups tend to desire the illumination of competing and oppositional movements. The violent and racist behaviour of the EDL and the BUF which they have demonstrated towards political rivals and ethnic minority communities confirms the 'extremist' element of their activism. Backes (2010, p. 192) also stresses that we should separate our understanding of 'extremism' with twentieth century totalitarianism as the 'extremism of the middle' can often point out the 'weaknesses and oversights of the political majority culture.' For this purpose, the Occupy movement is also included in this analysis as although they did not present a monocratic challenge to the existing constitutional structure, their political message did present a revolutionary critique of the existing political and economic structure which was resisted from the political mainstream. 
There is not sufficient space within one article to provide a comprehensive calculation relating to the proportion of policing bias present at political demonstrations, but the aim here is to illustrate and develop the argument that other, less politically motivated factors must also receive prominent attention. This article first analyses the policing of the EDL and Occupy movement in the contemporary period by the utilising current ethnographic research, reports on the policing of demonstrations, and newspaper reports whilst also considering the legal boundaries and precedents. The issues relating to the nature of the activism, the responses by the police and the evidence of political partiality are considered. From the historical period, primary source material has been gathered from a combination of digital and physical archives. This includes newspaper archives, Parliamentary debates, official reports, case law and legislation. The newspaper coverage of political protests reveal details of individual public order incidents for analysis. While the political bias of the newspaper, inaccurate reporting, and the stimuli for publishing stories must be taken into account, their value as a source is heightened when analysed in corroboration with other sources. Indeed, the police reports must also be read with a degree of scepticism as they will be worded in ways to ensure that the police response was necessary. Similarly, fascist, anti-fascist and communist accounts of conflict must also be questioned as there will always be a political agenda associated with its recording. For example, many complaints were recorded by the National Council for Civil Liberties (NCCL) about police brutality used against anti-fascist demonstrators. The NCCL agenda was to hold the police to account and ensure that freedom of expression was maintained for those who wanted to oppose fascism. Therefore, when using such sources to highlight police or fascist brutality, any transgressions by anti-fascists are not likely to appear in such accounts. 
The consideration of a variety of accounts from different perspectives offers a unique viewpoint into past conflicts between political activists and the police. Such a cross section can only be achieved by also considering the accounts of activists themselves. Although this also means providing a voice for the British far right, such interpretations must still 'remain firm in its fundamental condemnation' of fascism (Gottlieb and Linehan, 2004, p. 2). ${ }^{2}$ Including these often neglected voices ensures a more balanced approach in reconstructing the past. Finally, in appraising the police's responses to different political activists, the law also provides an integral element. The consideration of the legal powers available in both eras, as well as the actions taken by different groups under question can also help develop further factors on some of the inconsistency between the different types of responses made. The use of the historical investigation becomes valuable in identifying continuity and change within the policing of political activism. The factors raised which help explain the inconsistency in police practice in the 1930s still hold significance today. Similarities in the political movements' ideological perceptions of the police and their role also resonate in both eras. This then becomes an important aspect for analysis when examining the actions of each political movement and the police responses to them.

\section{Contemporary protests}

The present policing of political activism now recognises positive legal rights since the Human Rights Act 1998 has encoded the European Convention on Human Rights into UK law. This has shifted the burden of proof, effectively meaning that the police must enforce the least restrictive measures open to them and provide an objective basis for any conditions imposed in public order situations (Mead, 2010). While this has

\footnotetext{
2 The context which Gottlieb and Linehan used here was to argue that a study of the contemporary culture of fascism in the 1930s should not provide retrospective legitimacy to their political views. However, the same principle is still applicable to using records left by fascist activists.
} 
provided a legal foundation which may help prevent subjective practice, the accusations of politically motivated policing from the activists themselves continue. For example, Unite Against Fascism (UAF) claimed that the policing arrangements catered for the EDL, ensuring coaches and pubs were available for their demonstrations, while 'money was thrown at curbing effective anti-fascism' (Pai, 2016, p. 96-97). The police also face criticism from the EDL, who claim the police 'turn on their own people to appease the Muslim populations' (Lowles, 2011).

In recent years the political activism of the radical right and left have continued to use public space as a venue to deliver their propaganda. For the right, the march and grow tactic has been successfully utilised by the EDL (Jackson, 2011). Although the movement has now declined in membership and numbers at their public meetings and processions have dwindled, the societal factors which provided them with a springboard and public support (both tacitly and overtly) still remain (Winlow et al., 2016). On the other end of the political spectrum, the Occupy movement, which began in New York in September 2011 and influenced similar protests around the globe, established a novel style of activism by staging a single protest of an extended period of time by camping in public places. The protesters' aim was to stand up for the '99\%' and hold the 'anti-social rich to account' for social failures such as poverty, unemployment, low wages and homelessness (Winlow et al., 2015, p. 152).

At the height of their popularity, the EDL could mobilise large numbers of activists for public processions in towns and cities across England. ${ }^{3}$ The provocative nature of their activism included racist and anti-Muslim chanting. The EDL gained momentum under the leadership of Tommy Robinson (Stephen Lennon) as a small movement in Luton

\footnotetext{
3 'The Homecoming' demonstration at Luton on 5 February 2011 was reported to have attracted 3,000 members to the procession. See Channing (2015, p. 102) for attendance estimates from different sources.
} 
with a link to football hooligan firms (Garland and Treadwell, 2010). Paul Jackson (2011, p. 18) highlighted that the EDL updated the 'march and grow' strategy by fusing it with the 'new far right' cause of anti-Muslim sentiment which was 'centralised through internet mobilisation and online networking'. Their demonstrations also motivated large numbers of anti-fascist protesters which provided the police with the challenging task to facilitate rival protests.

The police response to the new threat of right wing activism resurrected similar complications to those faced in the interwar years. Who should action be taken against; the provocative right or the those provoked and motivated to disrupt them? By virtue of the Public Order Act 1986, the police held the power to apply for a ban on processions which was subject to the approval of the local council and the Home Secretary or to impose conditions upon them. This power has predominantly been used on the EDL and other far right groups on account of the anticipated disorder which would arise from the provocation style of activism. ${ }^{4}$ The EDL leadership presented a legitimate front. The official mandate stated that they were a peaceful, non-racist organisation that was only opposed to militant Islam (The Guardian, 28 Aug 2010; also, see current mission statement, English Defence League, 2016). The reality was that there was 'very real violence at the centre of some members activities' (Treadwell, 2015, p. 130). This frequently contradicted the claims of peaceful activism and respect for law and order which was promoted in the official rhetoric. For example, co-leader Kevin Carrol's speech at Dewsbury highlights the official rhetoric:

When we leave here today, I need you to respect and do as the police ask you... behave yourselves and be well mannered, we've got a great reputation

\footnotetext{
${ }^{4}$ See Freedom of Information Request submitted by lain Channing to the Home Office (Ref: 31049) Available at https://www.gov.uk/government/publications/applications-for-a-banning-order-under-section-13-of-thepublic-order-act-1986.
} 
now... the police know that we don't cause grief, we respect the police officers, they got a terribly difficult job to do... (Slacker1967, 2012).

Recent ethnographic research demonstrates that members did not necessarily share the same view of the police. One respondent in Winlow et al (2015, p. 114) stated, 'if I have to have a row with some coppers and have a row to get my voice heard, then bring it on.' The willingness to use violence as a political tool is also evident in another respondent who defended attacking both the police and Asian men by stating 'Violence is basically the only way people take notice' (Winlow et al., 2015, p. 115). The tendency of EDL members to engage in violence opposes the official rhetoric of being a non-violent organisation. This is problematic for the police who need to decide which preventative powers they use to minimise the opportunity for conflict. Although a procession ban could be applied for, the police could only place conditions upon public assemblies. At an early EDL demonstration at Leicester on the $9^{\text {th }}$ October 2010, the police had an application for a procession ban approved because of fears that they would attack mosques in the area. Therefore the EDL held a static protest, but they broke through police cordons and caused conflict and violence across the city. A report from Netpol highlighted many police failings which helped contribute to the disorder which included questioning the decision to ban the procession (Swain, 2011). The police used distraction and deterrent tactics to try and keep people away from the protest. This included the encouragement of youth clubs and community centres to provide activities to keep young people away, as well as issuing leaflets which highlighted that under the Children Act 1989, they held the power to take young people into police protection if they were thought to be at risk of harm. Netpol reported that this was the first time they were aware of this power being used in the context of political protest (Swain, 2011). 
When the EDL came to Leicester again in February 2012, the police response had transformed from one of containment to one of dialogue and the accommodation of a public procession (Treadwell, 2015). The police liaised with the EDL and facilitated their protest. Treadwell (2015, p. 134-5) highlights that the 'more retaliatory and forceful style of policing' began to decline between these periods and the 'softer approach' to policing EDL activism became more successful at preventing disorder. This is largely because the routes were particularly well coordinated and avoided potential 'flashpoints' (Waddington et al., 1987). In addition, such tactics were also able to facilitate both EDL and UAF protests through the use of dialogue policing and accommodating their protests in an orchestrated manner which kept them apart. While UAF have criticised such tactics for appeasing the EDL, the success of the response demonstrates an element of pragmatism which traverses the path of least resistance.

The policing of Occupy London reveals a mixture of responses which demonstrated both a commitment to human right conventions as well as tactics which were utilised to deny them. For example, the police formed a cordon to prevent protestors from demonstrating at Parliament Square. One Occupy organiser questioned the police's legitimacy by doubting the legality of the measure, while the author and environmental journalist Donnachadh McCarthy criticised the repression of free speech arguing, 'If you don't have free speech in front of parliament, you don't have free speech' (The Guardian, 22 Nov 2014). As is discussed below, this tactic of prohibiting protest in specific places is recurrent of those used in the 1930s against both far left and far right groups. The police attempts to engage with the protesters before the event also failed. Therefore, the absence of dialogue between both parties contributed to the police response and in effect led to doubts of legitimacy on both sides. This evidences that the historical suspicion that has existed between the police and the radical left is still 
relevant today (Alderson, 1984; Reiner, 2010). Further, Gorringe and Rosie (2013) have established that some police attempts to engage with left wing protestors before a demonstration can still be met with suspicion.

At the same time, the Occupy protests at St Paul's Cathedral and Finsbury Park which commenced in October 2011 were not evicted until the High Court ruled that the City of London Corporation could lawfully evict them. The Corporation then used bailiffs to carry out the eviction with the police present to maintain order. This decision is an indication that the police made a conscious attempt to remain politically neutral relying on the property owners to seek legal legitimacy through the courts. This is reminiscent of the standard practice of policing of Gypsies and Travellers where the onus largely falls upon the local authorities to hire bailiffs to move them on. Yet, in the case of Gypsies and Travellers and the Occupy movement, the police still engaged in certain enforcement led practices such as physical and virtual forms of surveillance and information gathering (James, 2007; Burgum, 2015). Burgum (2015) highlighted the paranoia and distrust within the Occupy movement who believed several people to be undercover police officers. Although there was no explicit hierarchical structure within the movement (Stott et al., 2013), unofficially there was a greater respect for members who had spent time in police custody or had been on the receiving end of police violence (Burgum, 2015). This further indicates the core anti-establishment culture within the movement that primarily saw the police as the frontline defenders of the system they campaigned against and criminal or deviant forms of direct action were championed by the groups. This resonates with how the political left have ideologically utilised tactics which opposed the police, while the leadership of the political far right have generally adopted an approach sympathetic to the police (Alderson 1984; Channing 2015). 
The individualism and libertarianism within the Occupy movement contributed to its own downfall as it created disorganisation and symbolic inconsistency which resulted in a failure to function as an organisation (Burgum, 2015). In addition, the promisingly radical movement which pledged to fight the democratic ideal, has since been criticised for conforming to liberal and reformist methods such as fighting the eviction through the courts and encouraging the signing of petitions (Winlow et al., 2015). Yet, at the same time the method of activism itself also led to its own ostracism. Research on Gypsy and Traveller communities highlights how nomadism threatens to subvert the conventional sedentary principles of an ordered society that standardizes settlement, private property and wage labour as cultural norms (James, 2006). In the same way, the Occupy movement threatened all these principles by temporarily using privately owned public space for residency and creating an image of an unemployed community. ${ }^{5}$ However, despite the radical nature of the activism, and the longevity of it which led the media and the citizenry to dismiss them as a 'political irrelevance', the protest had surprising durability considering the police's traditional commitment to keeping the highways free from obstruction. Although there is inherent ambiguity in this law which does not stipulate how wide a diversion around an obstruction needs to be for an offence to take place, the gravitas of the rights of assembly and expression has been extended since the Human Rights Act 1998.

\section{The interwar years}

In the period following the First World War, the socialist left made huge gains and the Labour Party also began to assert its dominance as a political force, forming a minority Government in 1924 and 1929. Other parties on the left such as the CPGB remained

\footnotetext{
${ }^{5}$ Although many occupants did have jobs there was a media focus on the homeless and drug addicts resident within the camp.
} 
on the periphery of the political mainstream despite some electoral success which saw three different candidates elected to Parliament at different points in this era. Despite this, they still maintained their radical and revolutionary identity. At the same time, a growth in ultra-nationalist politics of the far right developed and was dominated by the organisational capabilities of Sir Oswald Mosley's BUF. While the BUF had the resources to hold large indoor meetings, their activism was predominantly delivered on the streets in the form of selling newspapers, outdoor public meetings and public processions. With far right and far left activists competing for the prime locations to attract a receptive audience, and the common tactic of the left and anti-fascists to purposefully disrupt fascist meetings, this ubiquitously led to street battles (Channing, 2014; Thurlow, 2006; Anderson, 1983). The contemporary accounts and debates of this period that were instigated by left-wing politicians and civil liberty campaigners frequently challenged inconsistent police practice on the grounds of its perceived partiality. ${ }^{6}$ Their allegations were evidenced by a range of police actions, such as facilitating fascist processions while taking violent action against anti-fascist protesters, and allegedly turning a blind eye to gratuitous fascist violence and the unlawful use of abusive or insulting words or behaviour. The policing of such political rivalry therefore became in itself inescapably political, as previously noted.

While this research does raise critical issues in policing which need to be addressed, a micro analysis of the policing of British fascism highlights that there were multiple variables which add to the debate on the political nature of policing. Typically, incidents that have depicted the use of police coercion on far right activists have not been given the same academic attention. Therefore, when examining the policing of extreme

\footnotetext{
${ }^{6}$ For examples, see, HC Deb 10 July 1936 vol 314 cc1566, HC Deb 25 June 1936 vol 313 cc1943, R. Kidd, British Liberty in Danger, Lawrence and Wishart Ltd (1940) pp. 123-158 and The Hull History Centre (HHC), UDCL/75/2, NCCL Circular 'Police Discrimination'.
} 
political activism, a wide range of sources and incidents need to be analysed which highlight the variations of responses. These alternative views importantly reveal a more sporadic and inconsistent response to policing than previously thought, and while the intention of revealing a 'forgotten side' of policing does not address the balance, as pro-fascist policing did undoubtedly occur, it demonstrates that it was not always as politically motivated as has previously been described.

Ewing and Gearty (2000) provide a convincing and detailed argument regarding the political partiality of the police in the interwar period. They contend that the police frequently protected fascist activism while dispersing or arresting anti-fascists or not allowing the CPGB the same level of protection as the BUF. While there is evidence to support such frequent police tactics, the evidence does not take into account the behaviour of the different sets of activists, the regional variations within the police responses, or the legal options available when faced with rival crowds. Particular weaknesses lie in the lack of detail with regard to specific occasions used to bolster their claim. For example, they highlight how when disorder occurred in Plymouth on $13^{\text {th }}$ June 1934, two anti-fascists were arrested for assaulting police officers in the execution of their duty, and similarly in Bristol at an open air fascist meeting nine antifascist demonstrators were arrested and no fascists (Ewing and Gearty, 2000). Arguably, with a number of instances such as these an argument evolves that the police saw it as their duty to protect fascists. Yet, the more critical question is to ask whether the Blackshirts had broken the law themselves, and how legitimate it may have been for the police to take action against them on the grounds that their activism provoked or incited disorder.

The judgment in Beatty $v$ Gillbanks [1881-1882] clearly identifies that someone cannot be 'convicted for doing a lawful act if he knows that his doing it may cause another to 
do an unlawful act'. Therefore, if the BUF activism was lawful, the police were correct in targeting the anti-fascist protestors who deliberately disrupted fascist meetings. It therefore becomes questionable whether the police action should be seen as purposefully protecting the fascists, or more pragmatically dealing with transgressors. If the fascists were deemed to have provoked or incited the conflict then it could also have been seen as legitimate for the police to have coercively restricted their political activism. In Wise v Dunning [1902] it was highlighted that the Protestant street lecturer George Wise had regularly used insulting words and gestures which incited disorder between his supporters and local Roman Catholics. Here, the judges held Wise accountable for the disorder, stating that even if his actions were lawful in themselves, the 'natural consequence' of them were the unlawful breaches of the peace committed by others. Importantly, Wise's speeches did not only include insulting words against the Catholic inhabitants, but he also incited his supporters to bring sticks to the next meeting clearly identifying the potential for violent confrontation. The judgment in Wise $v$ Dunning strengthened the breach of the police doctrine as it recognised that public disorder may be the natural consequence of conduct or language that does not contradict any statutory law. In addition to the breach of the peace powers, there were also statutory powers relating to the use of threatening, abusive or insulting words or behaviour with the intent to cause a breach of the peace or where a breach may be anticipated. In London, these existed under s54(13) Metropolitan Police Act 1839, and later in England and Wales under s5 Public Order Act 1936, which specifically added 'at any public meeting' to explicitly demonstrate the aim of the provision.

Considering the availability of both common law powers under the breach of the peace doctrine and the statutory powers relating to threatening, abusive or insulting words or behaviour, then problems of consistently applying them become clear. They all contain 
contested notions. For example, what is a breach of the peace and when is it deemed to have happened? At what point can a breach of the peace be reasonably anticipated? What words or behaviour may be considered 'abusive'? Or even more vaguely, what is 'insulting'? ${ }^{7}$ These sorts of offences could be considered so wide that the use of discretion is essential in their application. Yet, to maintain legitimacy, they must also be applied consistently, fairly and without prejudice. Across England and Wales, practices varied and there were undoubtedly cases where the police did have a profascist stance. This is particularly highlighted by the circulars and testimonies recorded by the National Council of Civil Liberties. ${ }^{8}$ Accusations against Metropolitan Police officers include claims that the police laughed at the fascist's anti-Semitic speeches and used racist language when arresting Jewish protestors, highlighting deep-rooted cultural problems within the police and their relationship with minority communities. However, evidence of anti-Semitic or pro-fascist sensibilities within some police officers does not provide a suitable explanation for the wider issues relating to the policing of fascists more generally.

Firstly, the BUF were legally astute. Oswald Mosley had the knowledge, tactical prowess and the resources to confront potential legal challenges relating to their activism. The influence this had on his Blackshirts was made clear in a letter from BUF political officer Richard Plathen to Home Secretary Sir John Gilmour in 1934.

In short, there is nothing you or the members of the House of Commons can do to stop our practices... We know how to circumvent legal measures, and we have ample moneys and resources at our command to provide any further auxiliary legal machinery. ${ }^{9}$

\footnotetext{
${ }^{7}$ Incidentally, the term 'insulting' was again used in s5 Public Order Act 1986, but was removed in 2014 after a successful campaign known as Reform Section 5.

${ }^{8}$ U DCL/75/2, Duplicated circulars issued by the NCCL (1937-1938)

${ }^{9}$ The National Archives, Home Office, HO 144/19070, letter from BUF political officer Richard Plathen to Home Secretary Sir John Gilmour. 22 Feb 1934.
} 
The disturbances which became associated with the frequent BUF meetings became a constant drain on the resources of the police. In some regions the police took more pro-active measures to combat them. In Worthing, the West Sussex Police brought a prosecution against Mosley, William Joyce (who later became notorious as Lord Haw Haw) and two other BUF leaders for the common law offence of riotous assembly following 'disorder' at their meeting at the pavilion on the seafront. The case was sent to the Assizes ${ }^{10}$ where the judge instructed the jury to find them not guilty on account that there was no evidence of a 'common purpose' which was one of the five elements necessary for the offence. Although this prosecution would have originated from the higher ranks of the police which are more likely to have seen fascism as a public order problem, the case reveals how lower ranked officers supported the actions of the crowd. Giving evidence the officers identified that the fascists instigated the violence and crowd were mostly peaceable. This contradicted the fascist evidence that they were more 'sinned against than sinning' (Hull Daily Mail, 8 Nov 1934). While it may not be known to what extent the police evidence may have been manipulated to support the prosecution, the judge certainly felt it was by declaring that the police did not give evidence with the fairness he expected.

This case is interesting because it demonstrates a concerted police effort to establish that the BUF could be held culpable for 'disorder' associated with their activism. Although the prosecution declared that it was not a political prosecution but one to combat the 'discreditable and violent state of affairs on the streets', it held the potential to establish a common law legal precedent to restrict future BUF activism (Derby Daily Telegraph, 17 Dec 1934). Also, those injured were also said to have been not politically

\footnotetext{
${ }^{10}$ Before the introduction of the Crown Court, serious and indictable offenses were brought before the Court of Assizes and the Quarter Sessions.
} 
active to remove any element that they may have instigated any of the violence (News Chronicle, 9 Nov 1934). The evidence given by the police in the prosecution shows that low-ranking officers also provided evidence of an orderly crowd. Mosley's success in this case also demonstrates his legal astuteness and resources to challenge such actions. With his public claim that the prosecution was instigated by the Government who control the police (The Star, 13 Nov 1934), and Justice Branson's critical comments on the police's tactics and giving of unfair evidence in court, the police service's legitimacy was challenged and reputation damaged (Daily Telegraph, 19 Nov 1934).

The successful prosecution of BUF members required more robust evidence which proved that they were instigators of the violence rather than responding to the violence of other protestors intent on closing the meeting. One clear example occurred in Plymouth where a noisy (but non-violent) crowd disturbed a fascist meeting. A police officer present gave evidence stating that the speaker used a hand gesture and shouted, 'Go on boys, get stuck into them' which prompted three BUF members to strike out at anyone in their reach (Western Gazette, 23 Nov 1934). One man was struck several times and 'in a state of collapse' (Western Morning News, 13 Oct 1934). The three BUF members received six months' hard labour for committing a breach of the peace and assault. The charge of inciting a breach of the peace which was directed at the fascist speaker was dismissed. A further meeting at Plymouth Market demonstrated that the police were also very tolerant of political dissent at public meetings. The Western Morning News reported that the BUF meeting was subject to 'constant interruption, and many unpolite and unprintable remarks... [and that] a clash between the Socialist element and the Blackshirt guard which surrounded the lorry 
seemed imminent' (9 Feb 1934). Yet, despite the heckling and the potential for disorder the police (who attended in good numbers) did not interfere.

These two instances in Plymouth demonstrate that this city force did not routinely act with political motivation when policing crowds from rival movements and were willing to allow the fascist speeches and anti-fascist heckling to take place and only to take coercive action at the imminence of disorder. Yet, this varied across different forces. For example, there are examples within the Metropolitan Police which demonstrate a common tactic of preventing disorder by coercively silencing voices of anti-fascist dissent. Even comical chants such as 'Go back to Germany and eat German sausage' and political dissent such as 'fascism means hunger and war' saw the heckler arrested and charged with behaviour likely to cause a breach of the peace (The Times, 22 Oct 1934). In cases like this, the more overt police targeting of anti-fascist hecklers certainly supports the thesis that the police were protectors of fascist activism. The alternative course of action would be to target the provocative speaker, but this would have had much less chance of successful prosecution. Additionally, the police also have to judge the nature of the crowd because arrests are sometimes avoided to prevent 'potential confrontation that might spark disorder' (Waddington, 1998, p. 2). Even when arrests do occur following the use of explicit anti-Semitism, such as the case of John Penfold whose offensive speech angered a London crowd when he referred to Jews as 'usurers and parasites', in the courts he was only fined 40 shillings and used the prosecution to further his anti-Semitic agenda by alleging a Jewish influence on the criminal justice system (Nottingham Evening Post, 28 Aug 1936).

Additionally, in the prosecution of Arnold Leese, a rabid anti-Semite and Leader of the Imperial Fascist League, the jury returned a not guilty verdict for the charge of seditious libel. This is despite his words being beyond doubt as they were published in an article. 
Leese suggested that the available methods of dealing with the Jews included to kill, sterilise or segregate them and also accused the Jews of practicing ritual murder of Christians to obtain their blood for Passover ceremonies (Derby Daily Telegraph, 14 Aug 1936). Despite this, he was only found guilty on the lesser charge of creating a public mischief. Richard Thurlow (1994) highlighted that the Home Office viewed this verdict as a precedent; its effect was that the authorities refused to prosecute antiSemitic or racist libel unless it could be proved that it had provoked disorder. Although this case was related to printed material, its legal relevance to freedom of speech and provocation at public meetings is critical.

Despite the legal difficulties of securing a successful prosecution against fascist activists, the police did enjoy more success in the courts when impeding far left activism. Lord Trenchard, Metropolitan Police Commissioner, issued a ban on public meetings near the vicinity of employment exchanges in 1931. The rationale was supported by the Home Secretary who declared that such meetings had commonly ended in disorder (Hansard, HC Deb, 2 Dec 1931, vol314 c1551). The crackdown on socialist meetings highlighted the less favourable treatment afforded to socialist activists (especially within the Metropolitan Police district) as well as the broad scope of using the breach of the peace powers to limit political activism. Following the ban, several meetings were broken up by police and some ended in serious disorder (The Times, 28 Nov 1931). The legality of this ban was challenged by Katherine Duncan who attempted to hold a meeting outside an employment exchange in 1934. She was arrested by Inspector Jones for the obstruction of a police officer in the execution of their duty when she did not close the meeting on his request. The appeal harnessed the support of the National Council for Civil Liberties, with vice chairmen and MPs Dingle Foot and Denis Pritt representing the appellant. Despite claiming that the officer 
was not acting in the course of his duty by prohibiting the meeting citing the precedent established by Beatty $v$ Gillbanks, Lord Chief Justice Hewart dismissed the appeal on the grounds that there was no 'right' to public assembly and the officer was acting in the course of his duty because he reasonably apprehended a breach of the peace (Duncan v Jones, [1936] 1 KB 218).

This landmark decision had detrimental effects on claims to freedom of speech and assembly because of its wide interpretation of breach of the peace powers. It is also used as an example of the anti-left nature of policing (Ewing and Gearty, 2000). Yet, evidence also suggests that the police did take action against fascists at BUF meetings as well. Cullen's (1994) quantitative research using over 400 Metropolitan Police reports from BUF meetings between 1934 and 1938 demonstrate that $22 \%$ of those arrested were BUF members. ${ }^{11}$ This statistic, which includes the arrest of fascist speakers as well as those who were engaged in violence, may be disproportionate enough to support a claim of police prejudice but any critical examination of police practice must also consider other explanations.

What many BUF members became particularly astute at was to obey police instruction and to deliver their most flagrant anti-Semitic rhetoric when the police were distracted. It was reported that BUF speaker Clark moderated his language until senior officers were distracted. (The National Archives (TNA), MEPO 2/3115, Bow St Station, Report of Inspector James). Additionally, with the difficulty of securing prosecutions against fascist speakers, as noted above, it was more pragmatic to avoid arresting fascists unless a breach of the peace had been committed. Evidence also suggests that BUF members frequently followed Mosley's orders of obeying police instruction. For

\footnotetext{
${ }^{11}$ Cullen also notes that this figure could be higher because there is a category of $20 \%$ whose political alignment is unknown.
} 
example, BUF speaker Captain Collier agreed to close a meeting in Stockton-on-Tees at the request of the police who anticipated disorder from a hostile crowd. He stated that 'the Fascists were determined to obey law and order and help the police as much as possible' (The Northern Echo, 11 Sept 1933). The demonstration of the fascists' ideological position of compliance with the police here averted any conflict and such incidents will have a bearing on the statistics. The Chief Constable's police report emphasised the main motivation behind their tactics was to avoid disorder by removing the fascists from the town rather than make arrests of either fascists or anti-fascists (TNA, HO144/19070 Durham County Constabulary Special Report). While the perception of anti-fascists here is likely to view the police as protecting the fascists, as noted above in relation to the EDL, its aim must be seen as a pragmatic attempt at using available resources to pragmatically minimise any opportunity for conflict.

In Exeter, the Chief Constable Frederick Tarry went further by prohibiting a BUF speaker from addressing crowds at any other point other than an outdoor area known as the Triangle from 19 October 1937 onwards. The BUF speaker Captain Hammond had originally obeyed a request to close a meeting after the police anticipated disorder, and fearing further disorder Tarry prohibited him from speaking anywhere other than a designated space which was deemed less provocative (TNA, HO 144/21064. Disturbances: British Union of Fascists: Activities). Later issues of the Blackshirt highlight that Hammond obeyed the instruction and only spoke at meetings at the Triangle and despite the dubious legality of this proscription, this ban was not legally challenged. In a letter to the Home Secretary (TNA, MEPO 2/3116, Letter from Sir Oswald Mosley to the Home Secretary, 5 Aug 1937), Mosley claimed that the policing of fascist meetings in the provinces was not impartial. He used a meeting at 
Southampton as an example, where he accused the police of not taking any action against members of the crowd who threw stones and other missiles.

The examples provided above demonstrate that pragmatism may have played a large part in the police decision making process with regards to the political activism in the interwar years. While this does not discount that pro-fascist or anti-left policing did happen, it highlights alternative explanations for some of the inconsistences in police practice. Also, the restrictions placed on fascist activism or the under policing of fascist meetings also highlight that there was not a dominant discourse of pro-fascist approaches. The police in Exeter and Stockton-on-Tees prioritised methods which removed the fascist provocation, rather than dealing with those who threatened or caused disorder. In Worthing, a pragmatic attempt to hold the fascists to account for disorder, and therefore provide a legal basis for future prohibition failed. Such failures in prosecutions against fascist activists also played a key part in influencing police practice. In Plymouth and Southampton, the police demonstrated a tactic of monitoring and surveillance and only making arrests when it became necessary. These pragmatic responses from the rank and file and the chief constables demonstrate a willingness to achieve the role with the least fuss and paperwork (Reiner, 2010; Waddington, 1994). The variety of responses across the different forces also highlight the wide discretion available which accounts for the inconsistent approaches used against the far right and the far left.

\section{Conclusion}

There are some startling similarities within the methods of activism and the police responses to them during these periods. The difference today is that the positive legal commitment to the ECHR has prevented the police from restricting forms of protest without the imminence of disorder. Although, as with any form of crime prevention, 
such interventions still rely on the use of prediction which is filled by the 'very human process of implementation' (Gilling, 1997, p. 3). Decisively, as police tactics are judged retrospectively, their use of discretion in anticipating a breach of the peace and the actions taken to prevent it are inevitably open to criticism.

A key trend common through this historical comparison, is the theme of legitimacy. Primarily, the case of police legitimacy is important here as when activists perceive the police as acting illegitimately the chance for conflict escalates. Furthermore, a related factor here includes the tactics employed by the activists themselves as the willingness to accept police instruction (whether it is deemed as legitimate or not) is an instrumental predictor of conflict. The BUF's legal shrewdness meant that they knew how to deliver provocative political propaganda and contentiously stay within legal boundaries. Also, even when police responses were autocratic, instruction was usually obeyed and the police's authority was not challenged, which largely contrasts with the policing of far left activism. Here, by the BUF and the police recognising each other as legitimate in regard of their positions as political movement and law enforces, this did not necessarily mean that they agreed with each other's politics or actions, but were more prepared to accommodate and negotiate with each other. While the EDL lacked the organisational capabilities of the BUF, there is similarity in the leadership of both groups who encouraged their members to support the role of the police. While this may have been observed in many demonstration, there is evidence in both eras that their members embraced violent confrontations. The relationship between the police and the political left has been fraught with more suspicion, conflict and violence and the legitimacy of both are frequently called into question by the other.

The view that the police also engaged in tactics which hindered BUF activism is an unpopular academic view to establish. The dangers inherent in providing this 
alternative view are that it may be seen as a justification or defence of fascist activism, or that it presents a sympathetic account of the fascists as being unfairly treated. This is not the case. The reason for such a line of enquiry is to add critical depth to the question of policing political activism and the tensions involved in regards to keeping order between the politically provocative and the politically provoked. It does also not aim to disregard the institutional problems inherent in policing regarding police prejudice and unfavourable treatment of ethnic minorities. The literature here is beyond reproach. However, this does add how other police cultures also play a part in decision making in public order scenarios. Although Skidelsky (1975) has been criticised for his sympathetic account of Oswald Mosley and the BUF (Dorril, 2006) and his claim that the police were pragmatic rather than bias is too naive, this does not mean that pragmatism did not play any part in the policing of political activism. Important research has highlighted how influential pragmatism has been in influencing police decision making in public order scenarios (Waddington, 1994). As problem solvers, the police have frequently engineered ways to utilise the law to achieve simple and swift outcomes. This has been seen by the use of obstruction laws being used to minimalize disturbances, the prohibition of speakers in certain areas under the vague breach of the peace laws, or even the use of the Children's Act to prevent young people attending demonstrations. However pragmatic these responses may be though, the fact that these legal powers were being used in ways they were not necessarily created for leaves them open to abuse and selective enforcement. In addition, the ambiguity also contributed to wide regional variations in how the police responded to similar scenarios. By dissecting certain examples which evidence police coercion against politically extreme movements from either end of the political spectrum, it has been shown that while political prejudice should not be discounted, we should also 
consider the influence of other factors which motivate and influence the police decision making process.

\section{Reference List}

Alderson, J. (1984). Law and Disorder. London: Hamish Hamilton Ltd.

Anderson, G. (1983). Fascists, Communists, and the National Government: Civil Liberties in Great Britain, 1931-1937. Columbia and London: University of Missouri Press.

Backes, U. (2010). Political Extremes: A Conceptual History from Antiquity to the Present. London: Routledge.

Bartlett, P. (2007). “On Historical Contextualisation': A Lawyer Responds', Crimes and Misdemeanours 1(2): 102-106.

Burgum, S. (2015). Occupying London: Post-Crash Resistance and the Foreclosure of Possibility. Unpublished PhD Thesis: University of Warwick.

Busher, J. (2013). Grassroots Activism in the English Defence League: Discourse and Public (dis)order. In Taylor, M, Currie, P. M. and Holbrook D. (eds.), Extreme Right Wing Political Violence and Terrorism. London: Bloomsbury.

Dorril, S. (2006). Blackshirt: Sir Oswald Mosley and British Fascism. London: Viking Books.

Chan, J. (1997). Changing Police Culture: Policing in a Multicultural Society. Cambridge: Cambridge University Press.

Channing, I. (2014). Blackshirts and White Wigs: Reflections on Public Order Law and the Political Activism of the British Union of Fascists. Unpublished PhD thesis: Plymouth University.

Channing, I. (2015). The Police and the Expansion of Public Order Law in Britain, 1829-2014. Abingdon: Routledge.

Charlesworth, L. (2007). 'On Historical Contextualisation: Some Critical Socio-Legal Reflections.' Crimes and Misdemeanours 1(1): 1-40.

Cockcroft, T. (2012). Police Culture: Themes and Concepts. London: Routledge.

Deshmukh, S. (2016). 'Report on the policing of the English Defence League and Counter Protests in High Wycombe on April 9th 2016.' Network for Police Monitoring and High Wycombe Community Advocates. Available at https://netpol.org/wp- 
content/uploads/2016/05/Report-ofpolicing-of-EDL-and-Counter-demonstrationsApril-9-th-FINAL.pdf (accessed 4 December 2017).

Emsley, C. (1996). The English Police: A Political and Social History. Harlow: Pearson Education Limited.

English Defence League (2016). About us. Available at http://www.englishdefenceleague.org.uk/mission-statement/ (accessed 14 December 2016)

Ewing, K. D. and Gearty, C. A. (2000). The Struggle for Civil Liberties: Political Freedom and the Rule of Law in Britain, 1914-1945. Oxford: Oxford University Press.

Fenwick, H. (2009). Marginalising Human Rights: Breach of the Peace, "Kettling", the Human Rights Act and Public Protest. Public Law, 4: 737-765.

Garland, J. and Treadwell, J. (2010). "No Surrender to the Taliban': Football Hooliganism, Islamophobia and the rise of the English Defence League.' Papers from the British Criminology Conference 10: 19-35. Online at http://www.britsoccrim.org/volume10/2010 Garland Treadwell.pdf

Gilling, D. (1997). Crime Prevention: Theory, Policy and Politics. London: UCL Press.

Gorringe, H. and Rosie, M. (2013). "We will facilitate your protest': Experiments with Liaison Policing.' Policing: A Journal of Policy and Practice 7(2): 204-211.

Gottlieb, J., and Linehan, T. (2004). Introduction: Culture and the British Far Right. In Gottlieb, J. and Linehan, T. (eds), The Culture of Fascism: Visions of the Far Right in Britain. London: I.B. Taurus.

Jackson, P. (2011). 'The EDL: Britain's 'New Far Right' Social Movement.' The University of Northampton's Radicalism and New Media Research Group.

James, Z. (2006). 'Policing Space: Managing New Travellers in England.' British Journal of Criminology 26: 470-485.

James, Z. (2007). 'Policing Marginal Spaces: Controlling Gypsies and Travellers.' Criminology and Criminal Justice 7(4): 367-389.

Lawrence, P. (2012). 'History, Criminology and the 'Use' of the Past.' Theoretical Criminology 16(3): 313-328.

Lewis, D. S. (1987). Illusions of Grandeur: Mosley, Fascism and British Society 1931-1981. Manchester: Manchester University Press.

Loftus, B. (2009). Police Culture in a Changing World. Oxford: Oxford University Press. 
Lowles, N. (2011) 'Policing the EDL.' Searchlight 428: 6-7.

Macpherson, W. (1999) Inquiry into the matters arising from the Death of Stephen Lawrence: Final Report. London: The Stationary Office.

Mead, D. (2010). The New Law of Peaceful Protest: Rights and Regulation in the Human Rights Act Era. Oxford: Hart Publishing Ltd.

Newman, G. and Ferracuti, F. (1980). Introduction: The Limits and Possibilities of Comparative Criminology. In Newman G. (ed.), Crime and Deviance: A Comparative Perspective. London, Sage.

Oaten, A. (2014). 'The Cult of the Victim: An Analysis of the Collective Identity of the English Defence League.' Patterns of Prejudice 48(4): 331-349.

Pai, H-H (2016). Angry White People: Coming Face to Face with the British Far Right. London: Zed Books.

Slacker1967 (2012). EDL Dewsbury 30/06/12 - Kevin Carroll Speech. Available at https://www.youtube.com/watch?v=MkXEOW2Hzvc (Accessed: 14 December 2016).

Stevenson, J. (1980). The BUF, The Metropolitan Police and Public Order. In Lunn K. and Thurlow R. (eds.), British Fascism: Essays on the Radical Right in Inter-War Britain. London: Croom Helm Limited.

Stott, C., Scothern, M. and Gorringe, H. (2013). 'Advances in Liaison Based Public Order Policing in England: Human Rights and Negotiating the Management of Protest.' Policing: A Journal of Policy and Practice 7(2): 212-226.

Stone, R. (2001). 'Breach of the Peace: The Case for Abolition.' Web Journal of Current Legal Issues, accessed at http://webjcli.ncl.ac.uk/2001/issue2/stone2.html

Swain, V. (2011). Report on the Policing of the English Defence League and Counter Protests in Leicester on October $9^{\text {th }}$ 2010. Network for Police Monitoring.

Reiner, R. (2010). The Politics of the Police; Forth Edition. Oxford: Oxford University Press.

Renton, D. (2000). Fascism, Anti-Fascism and Britain in the 1940s. Hampshire and London: Macmillan Press Ltd.

Renton, D. (2017). Anti-Fascism in Britain 1997-2012. In Smith E. and Worley M. (eds.), Against the Grain: The British Far Left from 1956. Manchester: Manchester University Press.

Scarman, Lord (1981) The Scarman Report. London: HMSO.

Skidelsky, R. (1975). Oswald Mosely. London: Macmillan. 
Stone, R. (2001). 'Breach of the Peace: The Case for Abolition.' Web Journal of Current Legal Issues; http://webjcli.ncl.ac.uk/2001/issue2/stone2.html (accessed 23 January 2014).

Thurlow, R. (1994). The Secret State: British Internal Security in the Twentieth Century. Oxford: Blackwell.

Thurlow, R. (2006). Fascism in Britain: From Oswald Mosley's Blackshirts to the National Front. London: I B Tauris.

Treadwell, J. (2015). Controlling the New Far Right on the Streets: Policing the English Defence League in Policy and Praxis. In Chakraborti N. and Garland J. (eds.), Responding to Hate Crime: The Case for Connecting Policy and Research. Bristol: Policy Press.

Waddington, D., Jones K. and Critcher C. (1987). Flashpoints: Studies in Public Disorder. London: Routledge.

Waddington, P. A. J. (1994). Liberty and Order: Public Order Policing in a Capital City. London: UCL Press.

Waddington, P. A. J. (1996). Public Order Policing: Citizenship and Moral Ambiguity. In Leishman F., Loveday B. and Savage S. (eds.), Core Issues in Policing. London: Longman.

Waddington, P. A. J. (1998). 'Both Arms of the Law: Institutionalised Protest and the Policing of Public Order.' In Papers from the British Criminology Society Conference, Loughborough University, 18-21 July 1995. Online at http://www.britsoccrim.org/volume1/008.pdf (accessed 14 December 2016).

Winlow, S., Hall, S., Treadwell, J. and Briggs, D. (2015). Riots and Political Protest: Notes from the Post-Political Present. Abingdon: Routledge.

Winlow, S., Hall, S. and Treadwell, J. (2016). The Rise of the Right: English Nationalism and the Transformation of Working-Class Politics, Bristol: Policy Press. 